\title{
THE IMPACT OF VIDEO CONFERENCING PLATFORM IN ALL EDUCATIONAL SECTORS AMIDST COVID-19 PANDEMIC
}

\author{
Froilan D. Mobo \\ Assistant Director, Department of Research and Development \\ Philippine Merchant Marine Academy, Philippines \\ froilanmobo@gmail.com
}

Abdul Rahmat

Gorontalo State University

abdulrahmat@ung.ac.id

Received: 02 Oktober 2020; Revised: 21 November 2020; Accepted: 28 Desember 2020
DOI: $\underline{\text { http://dx.doi.org/10.37905/aksara.7.1.15-18.2021 }}$

\begin{abstract}
The Impact of COVID-19 Pandemic made the business world stop and also the economic sector. Health protocols standard has been observed like social distancing, the mandatory wearing of facemask, and avoiding mass gathering. The researcher is proposing to use a video conferencing platform beside the learning management system because this will replace the face to face setup and realtime feedback from the students to the teacher. Video conferencing has always been a key ingredient in the recipe to success for enterprises and other educational sector hoping to connect with customers, remote workers, and even with the students, (BEAUFORD, 2020). The results suggest that current policies and teaching strategies can be adapted due to the outbreak of COVID-19. In relation to previous studies on the use of videoconferencing in higher education, Video Conferencing such as Zoom and Google meet the demands in a broader consideration of the relevant challenges that arise when using certain videoconferencing systems in learning and teaching situations and that can be used in the current scenario, (Khatib, 2020). Using Video Conferencing will not violate any quarantine protocols and this will ensure the safety of both students and the teachers, in times like this, we really need to adopt the new technology platforms embracing the effects of COVID-19 and might lead to the opening of the New Normal in all sectors.
\end{abstract}

Keywords: Video Conferencing, Zoom Meetings, Google Meet

\section{INTRODUCTION}

The Impact of COVID-19 Pandemic made the business world stop and the economic sector. Health protocols standard has been observed like social distancing, the mandatory wearing of face mask, and avoiding mass gathering. The Department of Education and Commission on Higher Education is the process of adapting the mechanism of their learning strategy this coming opening of classes, most of the institutions will be using flexible learning this is to avoid face to face classes. The researcher is proposing to use a video conferencing platform beside the learning 


\author{
Volume : 07 \\ Nomor : 01 \\ Bulan : Januari \\ Tahun : 2021 \\ http://ejurnal.pps.ung.ac.id/index.php/AKSARA/index
}

management system because this will replace the face to face setup and real-time feedback from the students to the teacher. Also, even the various training, seminars, and conferences have been shifted to a new model. Video conferencing has always been a key ingredient in the recipe to success for enterprises and other educational sector hoping to connect with customers, remote workers, and even with the students, (BEAUFORD, 2020). The results suggest that current policies and teaching strategies can be adapted due to the outbreak of COVID-19. Comparative to previously conducted readings regarding the use of videoconferencing in the educational sector, they offer a broader consideration of relevant challenges that emerge when using certain videoconferencing systems in both learning and teaching situations especially in this time of the pandemic, (Al-Samarraie, 2019). Using Video Conferencing will not violate any quarantine protocols and this will ensure the safety of both students and the teachers, in times like this, we need to adopt the new technology platforms embracing the effects of COVID-19 and might lead to the opening of the New Normal in all sectors.

\title{
METHODOLOGY
}

The Researcher conducted series of interviews in students and teachers from different institutions using Facebook messenger, based on my data gathering I found out that most of the teachers and students are using the Learning Management System platform and video conferencing as their mode of instructions even in the seminars, training, and conferences we also use video conferencing as part of learning platform this to comply with the protocol set by the interagency task force on COVID-19. Even in my ongoing class right now in the Graduate School, we do use the standard platform Video Conferencing using Zoom and Google Meet. However, most Physicians have not used telemedicine as a routine part of their daily work but among the resources that can help them learn about telemedicine is Video Conferencing, (Wright \& Caudill, 2020).

\section{RESULTS AND DISCUSSIONS}

Based on the findings on the impact of the video conferencing is very effective to use this coming New Normal in the opening of classes and even in conducting pieces of training, seminars, and conferencing to prevent from the infection of COVID-19 and to follow the quarantine protocols set by the Inter-Agency Task Force on COVID-19 in the Philippines. Zoom video-conference meetings are a solution to maintaining engagement in online education including interactive conferences during the COVID-19 pandemic, (Carlson, 2020). In the New Normal Video Conferencing will immensely take place in meetings, classes online and conferences. Even in the conference shifted to a fully synchronous online experience due to the COVID-19 outbreak. With fully synchronous, we mean that participants jointly listened to presentations and can participate in live Q\&A and attended other live events associated with the said conference, (Bonifati et al., 2020).

Declarations

- Availability of data and materials: Not Applicable

- Competing interests: Not Applicable

- Funding: Not Applicable

- Authors' contributions: Not Applicable 
Acknowledgement:

- I would like to thank those who morally supported and inspired me to write this article namely:

- 1. Kenneth Froy Angelo Mobo

- 2. Ana Liza R. Garcia

- 3. Rev. Fr. William Monsalud

- 4. Marijoy S. Pagal

- 5. My IKSAD Family

- Without them, I wouldn't be able to finish this article

\section{References:}

Al-Samarraie, H. (2019, August 14). A Scoping Review of Videoconferencing Systems in Higher Education: Learning Paradigms, Opportunities, and Challenges International Review of Research in Open and Distributed Learning. Retrieved August 07, 2020, from https://www.erudit.org/en/journals/irrodl/2019-v20-n3irrodl04799/1062525ar/

BEAUFORD, M. (2020, April 28). With COVID-19 Spreading, Video Conferencing is Booming. Retrieved August 07, 2020, from https://www.uctoday.com/collaboration/video-conferencing/with-covid-19spreading-video-conferencing-is-booming/

Bonifati, A., Guerrini, G., Lutz, C., Martens, W., Mazilu, L., Paton, N., . . Zhou, Y. (2020, April 20). Holding a Conference Online and Live due to COVID-19. Retrieved August 08, 2020, from https://arxiv.org/abs/2004.07668

Carlson, E. (2020, July). COVID-19 and Educational Engagement. Retrieved August 08, 2020, from https://www.ncbi.nlm.nih.gov/pmc/articles/PMC7195013/

Yi-huai1, H., Jing1, J., Yong1, C., \& Juc, J. (n.d.). Remote monitoring system basis on $3 \mathrm{G}$ for ships. Retrieved July 28, 2020, from http://en.cnki.com.cn/Article_en/CJFDTotal-JCKX200902029.htm 
Volume : 07

Nomor : 01

Bulan : Januari

Tahun : 2021

http://ejurnal.pps.ung.ac.id/index.php/AKSARA/index

18 AKSARA: Jurnal IImu Pendidikan Nonformal 